\title{
REALMS OF VISITORS' EXPERIENCE TO ECOTOURISM IN BULUSAN VOLCANO NATURAL PARK, PROVINCE OF SORSOGON, PHILIPPINES
}

\author{
Niño R. Rebuya \\ Tourism Management Department \\ Partido State University - San Jose Campus \\ The Philippines \\ (ninorebuya@gmail.com) \\ DOI: https://doi.org/10.22452/jati.vol25no2.8
}

\section{Abstract}

Globally, the role of protected area is recognised as solutions to environmental, social, and cultural challenges based on the current 2011-2020 International Union for Conservation of Nature (IUCN) Strategic Plan. The growing popularity of natural parks has proven to be both an opportunity and a threat to its resources; it is an opportunity to maintain the high quality of visitors' experience, however, poses a challenge to conservation of resources for future generations. Hence, this study which employed mixed method of research that looked into the present status of Bulusan Volcano Natural Park (BVNP) as a local conservation area and assessed the visitors' experiences as to entertainment, educational, escapism, and esthetic. Data were gathered from 200 respondents composed of on-site same-day local visitors and selected volunteers in BVNP. Findings showed that BVNP as a conservation area is committed to address park's issues and concerns through its sound conservation strategies while fostering social and economic development with the active presence of Aggrupation of Advocates for Environmental Protection (AGAP) Bulusan, Inc. It can be noted that the four realms were experienced good by the visitors with emphasis on escapism which involves higher level of engagement and active participation in the natural settings and the destination's environment. The feeling of being isolated from the urban society is what BVNP makes more significant to visitors. However, entertainment products should be improved to give more authentic cultural (tangible and intangible) entertainment experience. Further studies can be conducted on the relationship of visitor experience and resource protection strategies in the park.

Keywords: conservation, ecotourism, natural park, protected area, visitor experience 


\section{Introduction and Background}

Globally, the role of protected areas is now recognised as solutions to environmental, social and cultural challenges based on the current 2011-2020 International Union for Conservation of Nature (IUCN) Strategic Plan. In the case of ASEAN region, its wealth in natural resources has significantly provide advantage to over 500 million people through provision of food, clothing and other biological goods and ecosystem services. These vast resources, however, are facing serious threats due to human activities, continued urban development, and natural calamities. In Southeast Asia, the establishment of protected areas (PAs) had long been used and recognised as a means to protect the natural environment, as well as regulate their uses. Over the years, the number of protected areas has increased both in the terrestrial and marine realms. However, results from various assessments conducted by ASEAN Member States (AMS) revealed that in spite of increased areas of protection, the loss of biodiversity has not been effectively addressed. This concern is also similar from the report of the ASEAN Centre for Biodiversity that ASEAN region remains challenged in delivering progress towards addressing the drivers of biodiversity loss, particularly unabated pollution and the exploitation of forests and wetlands brought by human activities and commercial development (ASEAN Centre for Biodiversity, 2010). With this dilemma, number of mechanisms has already been adopted by both government and civil society organisation towards conservation and preservation of natural resources among protected areas. According to Shyuji (2015), Southeast Asian countries should localise and transform the new thought for community-based projects and study how customs and traditional way of thinking could influence progress and conservation.

One of which is the adaptation of ecotourism concept which is recognised for natural protection, social conservation, educational recreation, and community-based development. According to Leung, Spenceley, Hvenegaard and Buckley (2018), tourism in protected areas is focused into the interactive relationship of the visitor to natural environments; cultural and heritage resources of the destination which provides experience to enhance personal growth; social understanding, and foster sense of responsibility to conservation issues.

In the Philippines, tourism is considered as one of the major economic drivers where natural resources are the primary assets of the industry for which it is dependent for continued growth and existence. With the country's presence of about 240 protected areas that are designated into several classifications (Coates, 2016), it is considered as one of the world's 17 "mega-diversity" countries with more than 20,000 endemic species of wildlife inhabitants. 
However, according to International Union for Conservation of Nature (IUCN) Red List of Threatened Species, the country belongs to 34 global biodiversity hotspots where high biodiversity and endemism experienced a high level of threat due to human pressure and unceasing development and consumption to natural environments. This problem is not far with other neighbouring regions within Southeast Asia. Hence, the presence of Protected Areas and Wildlife Bureau (PAWB) as one of the attached agencies of the Department of Environment and Natural Resources (DENR) is tasked to ensure that biodiversity conservation is given emphasis and protected from various threats.

While recognising the potential of these protected areas for tourism, ecotourism in the Philippines has been adopted by some of the natural park as a low-impact travel. It helps educate the tourist on responsible travel to natural areas where resources are highly susceptible; directly benefits local socioeconomic development, foster community participation and involvement that shall take control of the entire community-based tourism development; and promote respect to cultural fabrics (Lim, 2012). It is also recognised in providing nature-based experiences to visitors in a protected area and is dedicated primarily to the protection of natural and cultural heritage and at the same time enjoyment of visitors with conservation to biodiversity.

With this rise of ecotourism in the Philippines, the role of the government body in planning and policy making, implementation, evaluation, and monitoring is vital in assisting sustainable ecotourism practices and operations in the country (Lim, 2013). The focus should not just be limited on the conservation itself, but rather it should also look into the achieved visitors' experience and satisfaction to the resources. Measuring why people participate in outdoor recreation and what benefits from recreational experiences are significant considerations in park management since park experience includes an enhancement of human intellect and well-being that contributes for the preservation of the natural environment (Miller, Carter, Walsh, \& Peake, 2014). In tourism, the quality of the product should enhance visitors experience and must be maintained with an effective conservation and community development tool. The experience is what visitors take from the park that includes perceptions, feelings, and reactions with the surrounding

According to Manning (2001), the growing popularity of natural parks is an opportunity and challenge to park's management and its operation. It is an opportunity to maintain a high quality of visitors' experience to enjoyment in the park, and a challenge to conservation of resources both environmental and cultural without compromising the present and future needs of the generations. It is seen to be ironic that the popularity of the park is also a threat to the 
resources. Too many visitors may cause crowding that can impact both social and environmental conditions in the park which can also degrade the quality of visitors' experience because the opportunity to experience nature was the main factor that adds to the high level of satisfaction of visitors (Kafle, 2014). It is believed that the enhanced visitor experiences work with the achievement of ecological conservation. Their interaction with the place creates the visitors' experience (Jager \& Halpenny, 2012). Hence, it is important to understand the factors that influence visitors' experiences and take a necessary action immediately.

\section{Literature Review}

\section{Natural Park as ecotourism/nature-based tourism destination}

Generally, national parks are protected areas which are found in destinations with unique ecological and cultural features and values. It provides an opportunity to people to relax and enjoy the nature with ensuring the biodiversity conservation. Likewise, it is vital in the provision of recreational opportunities for nature experience, yet requires community support and sustainability (Weiler, Moore, \& Moyle, 2013).

Public protected areas, both land and marine based, and those designated as category I and II of IUCN protected area categories are the most important ecotourism venues by far, given that they do not only preserve outstanding natural environments, but also allow for the provision of compatible recreational activities such as ecotourism (Leung et al., 2018).

One of the motivations of a visitor to travel is nature as it likewise provides activities for tourism (Huijbens \& Benediktsson, 2013) and the accessibility to wildlife was the most significant antecedent to value (Thapa \& Lee, 2017). Thus, ecotourism was promoted in PA as a form of traveling to conserve natural areas with an intention of research, appreciation, and enjoying the scenery including its wildlife and existing cultural presence in an area (Ceballos-Lascurain, 1996). Further, it is defined as a form of tourism that involves visiting sensitive natural areas often supporting the conservation of its originality (Coria \& Calfucura, 2012) in which the main objective is the awareness and appreciation of the value of natural and cultural traditions that contributes to the conservation and protection of nature; empowerment of the local human resources, and have insignificant negative impact on the natural and socio-cultural environment of the place (Bejinaru \& Cozorici, 2016).

Indeed, this type of tourism, it promotes biodiversity conservation; socioeconomic development, and emphasises the importance of empowerment and ownership of local community to ensure the long-term sustainability of 
ecotourism operations (Snyman, 2012). In a premise of modern ecotourism, it is necessary to involve the local communities in the introduction to the implementation of a project. It is therefore essential that involved locals understood the cultural and economic, and sustainability of community engagement to ecotourism in protected areas. Tourism and community engagement activities can also help reduce possible threats from visitors (Otuokon, Chai, \& Beale, 2012). But more than this, it should be emphasised that ecological and environmental protection is the core content of ecotourism development and that each stakeholder must adhere to this notion (Wang, Zhong, Zhang, \& Zhou, 2014).

Newsome, Moore, and Dowling (2013), stated that nature-based; ecologically sustainable; environmentally educative; locally beneficial, and generate tourist satisfaction are the five key principles of ecotourism. Knowing that ecotourism and nature-based tourism has similarity in its kind and definition, it is recognised that this type of tourism development is one of the major components of the industry and therefore a studied and researched areas today.

In the Philippines, the development of ecotourism was crafted as a viable tool for sustainable development within the recreation zones specified in the protected area management plan. It ensured the full participation and understanding of the involved community and multi-stakeholders about the protection and management of natural resources that includes culture and indigenous knowledge and practices, environmental education and ethics, as well as the derived socio-economic benefits that will both benefit host communities and visitor satisfaction. As a matter of fact, the DENR has an approved guideline on ecotourism development for protected areas in a bid to support conservation efforts and sustainable use of natural resources. On August 6, 2013, the agency issued a Department Order No. 2013-19 which covers the various phases in the ecotourism planning and management process, including site assessment that will determine whether ecotourism management is the right strategy for a particular protected area.

The Ecotourism Management Plan has included the following strategies such as, zoning to determine how visitors can use certain areas of the park; visitor site planning to limit the impact of visitors on the natural environment; sustainable infrastructure design to harmonise facilities with ecological processes and natural beauty; visitor management to consider flow and behaviour of visitors, as well as support the site's carrying capacity, and revenue generation, including determination of applicable fees. All plans regarding this type of 
tourism development will be viewed by the Regional Ecotourism Committee and subsequently approved by the Protected Area Management Bureau (PAMB).

The success of the national ecotourism strategy outlines the spreading of wealth between economically stable parts of the country and impoverished rural areas; the conservation of historical and cultural sites, the promotion of environmental and conservation awareness; and the implementation of the educational programs and more. The success of the strategy led to a number of achievements in Philippine tourism (Lim, 2013).

\section{Understanding travel motivations and visitors experience in natural parks}

Understanding why people travel is the most fundamental question to study visitors' behaviour. The visitor has their own motivations that stimulate their individual interest for travel. These motivations may include physical, cultural, social, and environmental aspects. An understanding of what factors influence the visitors and host residence can assist in managing expectations (Snyman, 2012) and deliver expected experiences. In a natural setting where protected area serves as an endpoint destination of visitors, motivations may be attributed to physical and mental aspects which include physical comfort, safety, and natural environs, while mental elements include searching for meanings, connections, and connotations (Jurowski, 2009). In addition, visitors visiting a natural park are commonly connected for ecotourism activities such as developing skills and abilities to challenge the nature. These are considered primary motivations to visit protected areas (Kamri \& Radam, 2013).

Today, natural parks are promoted as a destination that offers unique nature-based products and activities for visitors searching for extraordinary experiences. People living in the urban areas that desire for a real ecosystem and those longing for a cleaner environment that cannot be achieved in their usual setting due to varied pollutions from water, air, and human activities have caused an individual to develop psycho-physiological imbalances. In this sense, the environment changes people to go outside places to find solitude and escape from societal stress in the urban. Tourist travel with nature because they want to feel and learn from the natural environment, socially engage with other people with the same interest, and actively interact with park's resources/ activities during their visit (Wolf, Croft, \& Green, 2019).

The experience is what visitors take from the park, providing opportunities for visitors to interact with park resources in a manner that it is both safe for visitors and leaves the resource un-impaired. As such, it is important that visitor experience may deal with individual emotions, impressions, relationships that should relate to park purpose, significance, and 
desired outcomes because quality experience could eventually result in support for nature and interests in conservation.

\section{Theoretical Framework}

This study has applied the theory of Pine and Gilmore (1999) on the Four Realms of an Experience for describing the experiences of the visitors in natural parks. Nowadays, experience is the new source of value (Kafle, 2014) as it is defined and understood in various ways such as a complex interaction of people to the setting and activities that involve social and natural environment in which they find themselves. It is a social-psychological phenomenon; influenced by expectations; the norms and values of the peers and the attributes of protected areas during the stay of the visitors.

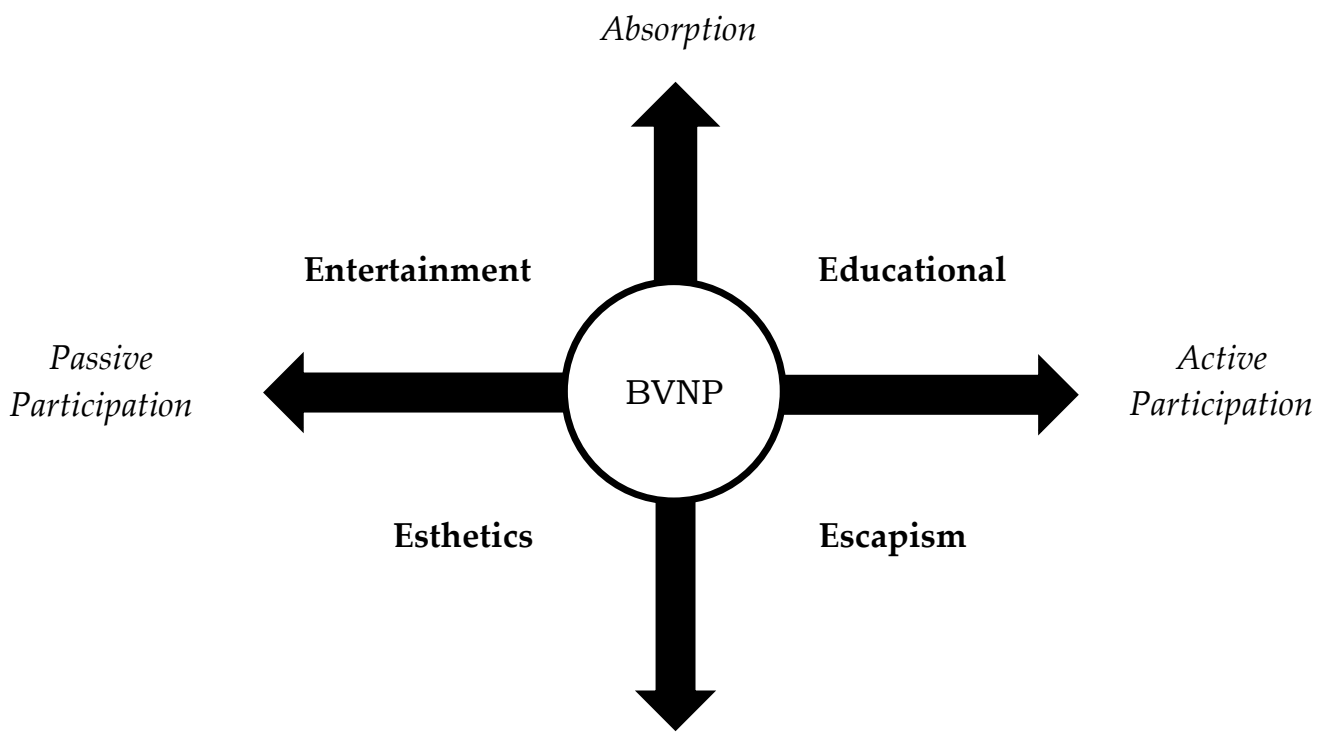

Immersion

Figure 1: The Four Realms of Experience

It is significant that an interpretative plan and resource protection strategy in a protected area describes the visitor experience opportunities that should be provided, hence this application of theory. Pine and Gilmore (1998) proposed that experiences embody four realms namely: education, entertainment, escapism, and esthetics that manifest across two dimensions (see Figure 1).

The first dimension indicates either active or passive visitor participation. Passive participation implies that the visitor does not physically exert effort into 
the activities, such as someone doing a bird watching and viewing cultural dance/song performances. Active participation, implies that the visitor plays a key role in creating the experience through their full and active physical, emotional, and mental involvements to any recreational activities being performed and participated in the destination, e.g., visitors doing a mountain climbing; joining into local dances and other cultural performances, and immersing to cultural practices of the indigenous tribe/people present in the area.

The second dimension comprises two extremes namely: absorption and immersion. Being absorbed in an experience implies being mentally involved in the experience such as watching a live cultural dance presentation, while immersion implies being physically involved in the experience, for example, when participating to cultural dancing.

The Entertainment is passive and absorption aspect of experience where visitor enjoys the experience watching others performing and made their mind engaged with the event. This kind of experience makes customer associated with the performer in an event that simply enjoys it by them (Pine \& Gilmore, 1999), likewise, this is a kind of traditional perception of experiences. In natural parks, these include the cultural presentations of indigenous dances/songs and other cultural manifestations that can be showcased to visitors.

The second field of experience realms is Education which is categorised for absorption and active participation. This type of experience increases the visitor skills and awareness from active participation in recreational activities where they can actively engage their mind. It is also absorption of the information or activities which intends to explore the knowledge and provide new learning opportunities and experiences to visitors in the destination. Attending to scientific tours within the natural park is an example of this experience.

The Escapism is considered to be an active-immersion aspect of tourism experience which involves a higher level of visitor engagement and active participation in the real settings and destination's environments. First-hand experience and understanding of cultural practices, social behaviour, natural attractions/resources and even the presence of an adventure and nature-based activities in the area are good examples of this experience. This kind of experience also gives an opportunity to visitors to explore novel things which are not familiar and associated with their everyday lives.

Esthetic is recognised in the realms of experience as passive and immersion where visitor enjoy the event without putting any effect on them. The purpose of this experience is being able to use the senses that contribute to the 
desired experience in the park. Appreciation of attractions or activities is usually experienced by the visitor during the encounter.

In general, the four realms of an experience indicate that entertainment is about sensing, education is a learning experience, escapism is discovery while doing, and esthetic is just about the appreciation.

The development and application of the four experience realms have been examined in various leisure and tourism contexts such as museum experience (Radder \& Han, 2015), and recreational experience types in relation to customer retention in leisure farm. However, during the course of the review of related literature and studies specifically on the theoretical use of this experience realm, it was noted that this theory is not yet applied to the visitor experience in protected areas, particularly to natural parks. Hence, this study which determined the present status of BVNP as a local conservation area and assessed the visitors' rating of their experiences at BVNP, as to: entertainment, educational, escapism, and esthetic.

\section{Methodology}

\section{Research Design}

The mixed method research design was employed in this study using qualitative and quantitative techniques. Qualitative method according to Denzin and Lincoln (1994) is aimed to gain a richly detailed understanding of a particular topic on first-hand experience, interview, and direct observation. It is also used to study things in natural settings, an exploratory method of inquiry that typically involves investigating unknown subject matter, sensitive topics, or difficult to access population. Furthermore, it is also defined by naturalism and interpretation (Frank \& Polkinghorne, 2010). Hence, its application in this study to present, discusses, and understands the present status of Bulusan Volcano Natural Park as a local conservation area. The quantitative method was directed towards presenting, analysing, and interpreting the data relevant to visitors' experience.

\section{Research Instruments}

The researcher utilised the following data gathering instruments/tools namely: survey questionnaire, interview guide questions, and focused group discussion.

Survey questionnaire: This instrument contained questions pertaining to the qualities and variables to describe the visitors' experiences at BVNP.

Interview guide questions: This was used in gathering the data to describe the present status of BVNP as a local conservation area. Likewise, this was done to validate some information relevant to the study. 
Participant observation: This was simultaneously conducted during the site survey and immersion at BVNP with the selected local visitors and other selected volunteers working in the park. This activity was done through informal interview, response clarifications, and follow-up questions to ensure the consistency and relatedness of each respondent's responses.

To ensure the validity of the research instrument, the survey questionnaire was content validated by three (3) experts in the same field but in various professions namely: academe, park management and administration, and Integrated Protected Area System (NIPAS). In the same manner, to guarantee the suitability of the items and identify the errors in the instruments and moreover, to determine the estimate of the length of time needed to accomplish the said instrument; a dry-run was conducted to the field test consisting of thirty (30) respondents. Also, to ensure the reliability of the instrument, Cronbach's Alpha was utilised to determine the internal consistency or average correlation of the items contained in the survey questionnaire to gauge its reliability. Further, the comments and suggestions during the validation process and dry run were considered and incorporated in the final research survey instrument.

\section{Respondents}

This study was conducted and administered to two hundred (200) respondents consisting of on-site same-day local visitors visiting the park and selected volunteers working within the BVNP. The survey was delimited to respondents whose ages are ranging from below twenty (20) years of age, 21-30, 31-40, 41-50, 51-60, and 61 to above years old, and the administration of survey was conducted during the months of September, October, November, and December in the entire Bulusan park. Furthermore, an interview was also performed to the key officials and key informants of BVNP administration particularly to AGAP Bulusan, Inc. and other selected volunteers working for a year within the park. This study excludes researchers conducting scientific studies within the site.

\section{Sampling Techniques}

This study used the Convenience Sampling Technique. It is a sampling technique in which every possible respondent has the same chance of being selected during the conduct and administration of survey questionnaire within the BVNP. To ensure randomness, and therefore representativeness, the surveys are operated in stationary and attraction site survey. In a stationary way, the researcher conducted the survey at the exit site of the park. While, in the attraction site survey, the researcher scouted visitors to answer the survey at the specific site 
within the park while visitors are on the resting sites, cottages, benches and/or picnic areas.

\section{Statistical Treatment of Data}

Weighted mean: This tool was applied in describing the visitors' experience and its level of agreement/disagreement.

$\begin{array}{cc}\text { Scale } & \begin{array}{c}\text { Verbal } \\ \text { Interpretation } \\ \text { Very Good }\end{array} \\ 3.25-4.00 & \text { Good } \\ 2.50-3.24 & \text { Fair } \\ 1.75-2.49 & \text { Poor } \\ 1.00-1.74 & \end{array}$

Standard deviation: It was used to determine the homogeneity/heterogeneity in the ratings of the respondents regarding their experiences as to the entertainment, educational, escapism, and esthetic.

\section{Study Setting}

This study was conducted at the Bulusan Volcano Natural Park also known as BVNP situated at the Municipalities of Bulusan, Casiguran, Barcelona, Irosin, and Juban Province of Sorsogon, Region V (Bicol), Philippines. Its location also lies in the southern tip of Luzon Island, near Camarines Peninsula and the southernmost part of the Sierra Madre mountain range. It covers a total area of 3,673.29 hectares comprising of Bulasan (1,580 has/43 per cent), Irosin (1,048 has/28 per cent), Juban (280 has/8 per cent), Casiguran (510 has/14 per cent), and Barcelona (255 has/7 per cent) (see Figure 2).

The destination was declared National Park through Presidential Proclamation No. 811 dated June 07, 1935 as Bulusan Volcano National Park and was reclassified as Protected Area under the category of Natural Park on November 27, 2000, proclaimed as Bulusan Volcano Natural Park by Presidential Proclamation No. 421 (BVNP: As Local Conservation Area).

BVNP features the three main peaks namely: Bulusan Volcano, Sharp Peak, and Mt. Jormahan, and three lakes such as Black Bird's Lake, Aguingay Lake, and Bulusan Lake. Aside from these varied landscapes and waterscapes. It also inhabited varied flora and fauna in which 63 per cent comprising of bird species, 13 per cent are reptiles, and 12 per cent amphibians (see Figure 3). 


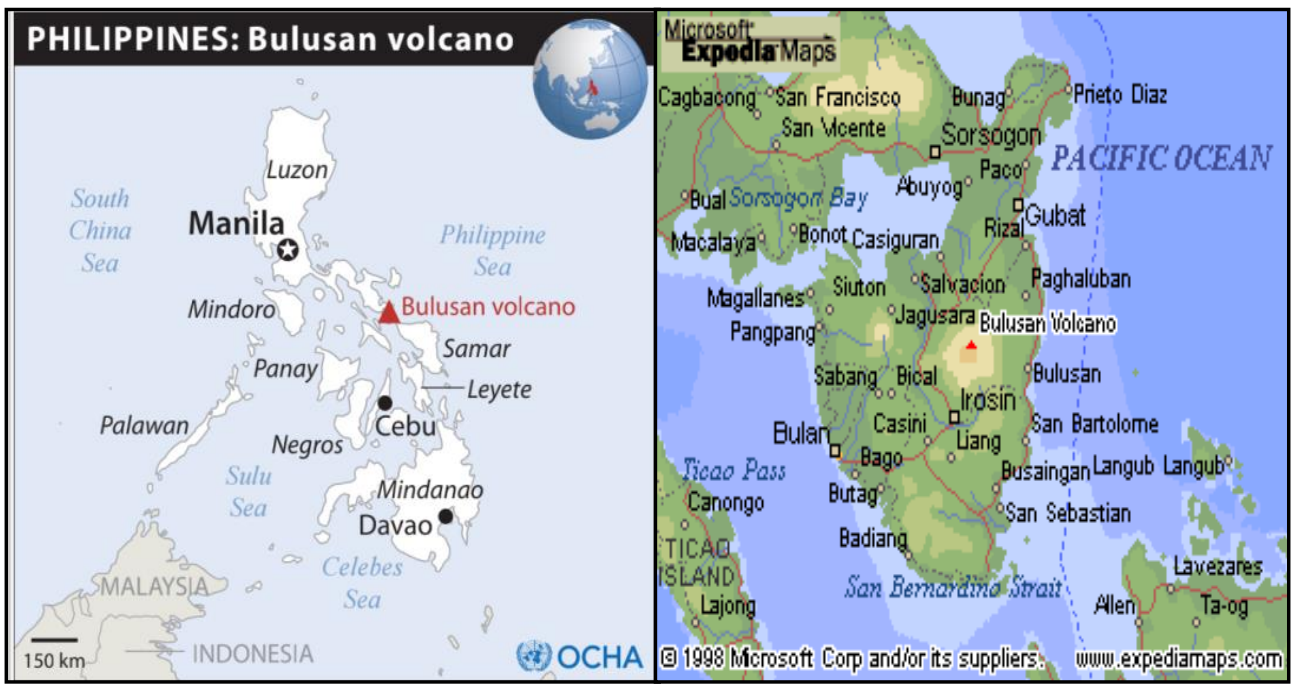

Figure 2: Location map of Bulusan Volcano Natural Park (Source: Europa Technologies, Gov't. of USA, UNCS.)

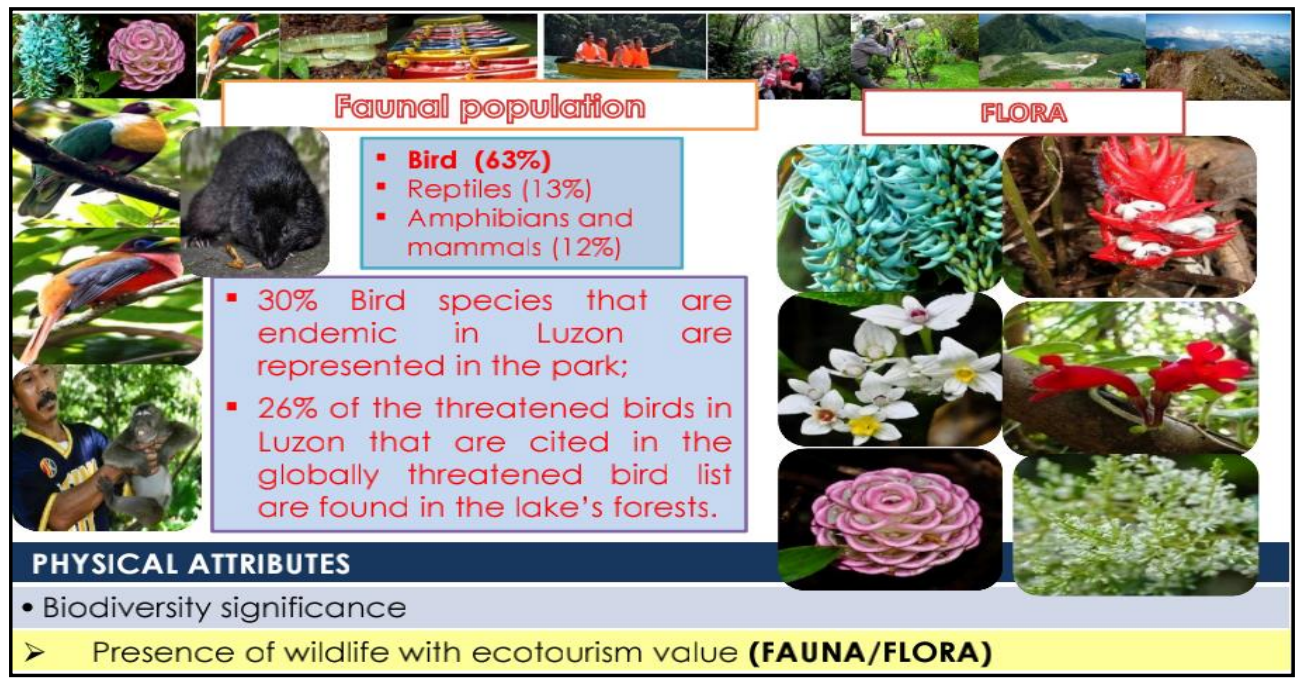

Figure 3: Physical attributes of Bulusan Volcano Natural Park (Source: “Bulusan Volcano Natural Park (BVNP) [n.d.].)

With the presence of these wildlife and unique physical attributes of the park, it is recognised and promoted as an ecotourism destination in the country where it offers a wide range of recreational activities like bird watching, trekking, volcaneering, kayaking, canoeing, aqua-cycling, row and long boating and other nature-based and Bulusan Lake aqua adventures.

\section{Results and Discussion}




\section{Present Status of Bulusan Volcano Natural Park as a Local Conservation Area}

Bulusan Volcano Natural Park also known as BVNP in Sorsogon is one the most conserved natural areas and famous ecotourism destinations in the Philippines. Designated as National Park pursuant to Presidential Proclamation No. 811 on June 07, 1935. Due to cultural, economic, aesthetic, and environmental values of the Bulusan Volcano's ecosystem and to protect the biodiversity of both flora and fauna, it was re-proclaimed as Bulusan Volcano Natural Park under Presidential Proclamation No. 421 dated November 27, 2000.

Bulusan Volcano, formed about 40,000 years before the present era, soars 1,565-metre high over a base diameter of 15 kilometres. It has three main peaks namely: Bulusan Volcano, Sharp Peak, and Mt. Jormahan and three lakes such as: Black Bird's Lake, Aguingay Lake, and Bulusan Lake. With its rich biodiversity, it provides agricultural livelihood and sustains the basic needs of local communities, thus recognising it as one of the Philippine Biodiversity Conservation Priority Setting Programs or Key Biodiversity Areas of the country.

However, this park has also undergone challenges such as unabated illegal activities within the PA. Hence, on May 2005, a memorandum of agreement was entered into by and between the BVNP-PAMB and LGU Bulusan giving the authority to the LGU Bulusan to co-manage and conserve the Bulusan Lake area up to 2 kilometres radius, and to develop its ecotourism potential to sustained economic growth and development of local communities living adjacent the PA.

On this recognition and responsibility, the Aggrupation of Advocates for Environmental Protection (AGAP) Bulusan, Inc. was born. It is a registered and accredited civil society organisation envisioned to address the environmental issues and concerns in the locality. AGAP Bulusan primary's mission is to protect and conserve the environment while at the same time fostering social and economic development thru: massive and intensive information and education campaign; introduction, promotion and support for sustainable eco-enterprise; resource mobilisation and linkaging; environmental research and data banking; and formulation and recommendation of environmental-related policy governing bodies or entities.

The establishment of AGAP Bulusan was at the same the creation of Preserve BVNP thru the UNDP Programme which are aimed on restoration; maintenance and protection of biodiversity and enhancement of ecotourism attractions of BVNP Bulusan Area; provision of capacity building and resource mobilisation as a poverty alleviation mechanism and enhancement; environmental awareness; information and education campaign on biodiversity conservation, and environmental management research and data banking. As a 
conservation area, it adheres to conservation strategies with focus on IECs, participatory reforestation, ecotourism/eco-livelihood trainings, community organising and capacity building, biodiversity watch and research, and community nursery establishment.

A year ago, BVNP through AGAP Bulusan has signed a MOA between Investments in Loving Organizations for Village Economies (ILOVE) Foundation, Inc. represented by Chairman and President Ms. Regina Paz L. Lopez in search of loving organisations working with marginalised communities into viable agroforestry, fisheries, or eco-tourism sites on December 13, 2018.

The soundness of BVNP through AGAP Bulusan, Inc. as to environmental and social conservation was evident on the various programs and projects being implemented to its concerned community residents, such as: the Bulusan through AGAP Inc. bagged the "Tayo ang Kalikasan" or "We are Nature" Regional Pilot Site for Environment Stewardship by the DENR working to eradicate illegal cutting of trees, poaching, slash and burn farming, as well as, in maintaining the highest quality of water as nominee for national cleanest river awards in 2019 and taking up the challenge to bring back its mangroves and reefs for sustainable coastal, island and marine resource management; the Bulusan Lake Pasalubong Centre and PRESERVE MRS Bulusan Social Enterprise Strategic Development Planning with MSMEs Handicraft and Wearables (H\&W) and Processed Foods (PF) facilitated by DTI were also conducted to increase productivity and profitability of the Bulusan entrepreneurs; a Mangrove Planting with ILOVE Foundation, Inc. and PRESERVE MRS (Participatory Restoration with Ecolivelihood Support, Education, Research, Ventures, and Eco-agritourism for Mountains, Rivers, and Seas) Bulusan; and an Integrated Coastal Resource Management Project (ICRMP) to increase productivity and profitability of 200 Fishers in the coastal communities in Brgy. Dancala as a Poverty Reduction and Climate Change Resiliency Mechanism through Sustainable Conservation \& EcoAgritourism Development under the PRESERVE MRS Bulusan \& Tayo ang Kalikasan Project implemented by AGAP Bulusan, Inc. in partnership with Barangay, Municipal and Provincial LGUs of Bulusan and ILOVE Foundation.

BVNP in Bulusan Ecotourism Success Story was featured in United Nations World Tourism Organization's (UNWTO's)-Tourism for Sustainable Development Goals (SDGs). At present, BVNP and AGAP Bulusan is now strengthening the ecologically and socially responsible tourism parameters through environmental education; revenue generation; livelihood, biodiversity conservation, visitor appreciation, and cultural exchange. BVNP is also currently working its application on UNESCO Global Geopark (GNN) which is believe to foster multi-cultural links between heritage and conservation and the 
maintenance of geological and cultural diversity using participatory schemes of partnership and management.

Moreover, continual improvements through on-going projects and programs are also implemented in BVNP to ensure sustainability such as organisational formation; strengthening and development; livelihood promotion and development, and sustainable natural resource management.

BVNP aside from being a local conservation area, it is also developed and promoted for ecotourism. The development of ecotourism activities within the PA has provided eco-livelihood trainings and establishment of social enterprise system to empower and increase profitability among members of the host community. This indicates the continued growth and recognition of the park's ecotourism products such as kayaking, canoeing, aqua-cycling, row and long boating, and other Bulusan lake aqua adventures the same with bird-watching, trekking, volcaneering, and other outdoor recreational activities in BVNP.

It can also be observed the initiatives being done by the AGAP Bulusan, Inc. to strengthen ecotourism business and sustainable operation within the park through number of partnerships and sponsorships, such as: the forging sustainable partnership for Bulusan outdoor eco-adventures; official turn-over of mountaineering gears from Mountaineers by ILOVE Foundation Program and as part of PRESERVE MRS Bulusan Project by AGAP Bulusan, Inc. to accelerate increase in profitability of eco-agritourism as a social venture in partnership with Barangay, Municipal and Provincial LGUs, BVNP PAMB, NGAs, and Private Sectors; and community-based pro-poor health and wellness, culinary and agritourism development in Bulusan.

Furthermore, a basic mountaineering and paragliding training course cum trail, camp and paragliding site assessment and mapping were also conducted as part of the annual skills education of the park volunteers and guides, and the Tourism Sorsogon has turn-over App to Bulusan Tourism Smart Guide.

In general, with the presence of active organisations, leaders and community residents of Bulusan and with an on-going aforesaid projects and programs as well as partnership and linkages with other related agencies, BVNP is really committed towards conservation efforts and sustainable tourism development.

\section{Visitors' Experience at Bulusan Volcano Natural Park}

\section{Entertainment}

Table 1 presents the result of the visitors' entertainment experience in Bulusan Volcano Natural Park. It was noted that the "Performance of park guides in the 
delivery of tour commentary" were experienced "Good" by the respondents with a highest mean of 3.24. This indicates that the park guides are competent in performing their guiding profession in the park considering that all of them were certified tour guides by the Technical Education and Skills Development Authority (TESDA) and at the same time accredited local tour guides of the Department of Tourism-Region V (DOT-ROV). Moreover, this positive rating can also be credited as a result of series of proper education and enhancement trainings and workshops conducted by AGAP Bulusan to its park guides such as personality development and communication skills and naturalist/eco-guides trainings. These volunteer guides also demonstrated their sense of humour through performing dances and songs which makes more entertaining for visitors; their enthusiasm and commitment in the delivery of tour guiding services to its tourists is also commendable.

Likewise, "Good" rating of 2.79 mean was also attributed to "Waterbased recreational activities in the park" which includes the kayaking, canoeing, aqua-cycling, row and long boating, fishing, and other Bulusan lake aquaadventures. This good result is due to well-maintained natural setting and cleanliness of the lake as well as in good condition water-based recreational facilities and equipment offered to visitors. Furthermore, the visitors were also given proper orientation or briefing by the assigned guides before engagement to activities and likewise they were informed of the carrying capacity as well as on the rotation of time allotted for each group.

Similarly, a "Good" rating of 2.70 mean was also experienced by the visitors to "Land/mountain-based recreational activities" such as bird watching, trekking, mountaineering, volcaneering, and camping. This result reflects on the conservation efforts by the BVNP management since these land-based attractions are protected with path walks, railings, and other structures which are designed to minimise and/or prevent the possibility of undesirable impacts brought by visitors' activities. In addition to it, each tour group has a designated park rangers and guides who gives direct orientation on the rules and regulations as well as to the expected behaviour while performing activities within the park. Each visitor is also given proper protective equipment prior to participation in activities especially mountain-based recreations. 
Table 1: Entertainment Experience in Bulusan Volcano Natural Park

\begin{tabular}{|c|c|c|c|}
\hline Entertainment & Mean & S.D. & V.I. \\
\hline $\begin{array}{l}\text { 1. Water-based recreational } \\
\text { activities in the park } \\
\text { (kayaking, canoeing, aqua- } \\
\text { cycling, row and long } \\
\text { boating, fishing) }\end{array}$ & 2.79 & 0.704 & Good \\
\hline $\begin{array}{l}\text { 2. Land/mountain-based } \\
\text { recreational activities (bird } \\
\text { watching, trekking, } \\
\text { volcaneering, } \\
\text { mountaineering) }\end{array}$ & 2.70 & 0.642 & Good \\
\hline $\begin{array}{l}\text { 3. Live cultural shows at the } \\
\text { reception area }\end{array}$ & 1.60 & 0.723 & Poor \\
\hline $\begin{array}{l}\text { 4. Outdoor park's displays } \\
\text { and exhibits }\end{array}$ & 2.23 & 0.843 & Fair \\
\hline $\begin{array}{l}\text { 5. Performance of park } \\
\text { guides in the delivery of } \\
\text { tour commentary }\end{array}$ & 3.24 & 0.533 & Good \\
\hline $\begin{array}{l}\text { 6. Souvenir shopping in the } \\
\text { park }\end{array}$ & 2.43 & 0.630 & Fair \\
\hline Overall & 2.50 & 0.543 & Good \\
\hline
\end{tabular}

On the contrary the aforementioned good entertainment experiences, a "Fair" rating of 2.43 mean was experienced to "Souvenir shopping in the park" by the respondents. Based from the result, this indicates that the visitors were unhappy of the shopping experience in BVNP considering that some of the items are not locally produced and are just delivered by the suppliers. It was also observed during the conduct of research immersion that some of the vendors are just labelling the souvenir items to be more personalised while the products are not locally handcrafted. The novelty of the items is also not achieved since there are similar products that can be bought and seen to other tourist destinations and they just simply differ on the label of the place. Cruz (2017) said that to satisfy tourists, gifts, and souvenirs for should be manufactured in the locality where the purchase is made.

The same "Fair" rating of 2.23 mean was also given to "Outdoor park's displays and exhibits". This finding is reflected on obsolete displayed posters, tarpaulins, and other printed materials at the entrance and receiving area of the park. It was also noted that some of the pictures are not supported with an interpretation as to the nature and description of the attraction and/or species. 
However, "Poor" rating of 1.60 mean was experienced to "Live cultural shows at the reception area". This result is also very evident considering that the supposedly cultural performances were translated into other shows which can be considered commodified from its authenticity where the performance is modified for tourist entertainment called trivialisation in which the real value why a tradition is done is lost because said event would then be done for visitors.

The overall rating in "Entertainment experience" of visitors was "Good" at 2.50 mean.

\section{Educational}

Along with educational experience of visitors in BVNP as presented in table 2, the "Information given park rangers and tour guides" were rated with a highest mean of 3.33 and experienced as "Very good". This positive result is consistent with the findings in table 1 that the performance of park guides in the delivery of tour commentary was good and is manifested on the aforementioned qualifications and initiatives of the park management to ensure park guide's competence, enthusiasm, and productivity. The park guides are indeed informative considering that they are also the resident of area themselves.

Table 2: Educational Experience in Bulusan Volcano Natural Park

\begin{tabular}{|c|c|c|c|}
\hline Educational & Mean & S.D. & V.I. \\
\hline 1. Information boards & 3.09 & 0.335 & Good \\
\hline 2. Directional signs & 3.13 & 0.371 & Good \\
\hline $\begin{array}{l}\text { 3. Information given by } \\
\text { park rangers and tour } \\
\text { guides }\end{array}$ & 3.33 & 0.470 & $\begin{array}{l}\text { Very } \\
\text { Good }\end{array}$ \\
\hline $\begin{array}{l}\text { 4. Brochures, maps, and } \\
\text { other printed materials }\end{array}$ & 2.88 & 0.501 & Good \\
\hline $\begin{array}{l}\text { 5. Opportunities for } \\
\text { learning about and } \\
\text { experiencing natural and } \\
\text { cultural attraction within } \\
\text { the park }\end{array}$ & 2.76 & 0.542 & Good \\
\hline $\begin{array}{l}\text { 6. Opportunities to } \\
\text { experience traditional } \\
\text { ways of life }\end{array}$ & 2.38 & 0.545 & Fair \\
\hline Overall & 2.93 & 0.301 & Good \\
\hline
\end{tabular}


Respondents were also rated 3.13 mean interpreted as "Good" on the "Directional signs" in BVNP. This shows that the visitors can easily navigate specific areas of point of interest within the park due to presence of directional signs installed and designated at the strategic areas and/or locations in Bulusan Park which are also translated into English and local dialect printed in a wide tarpaulins and sign boards to provide more visible look.

In the same manner, the "Information boards" were also experienced "Good" by the respondents with a mean of 3.09. This implies that the information boards are educational and provides self-interpretation of the species, attractions, as well as park rules and regulations. The information boards are very notable from the entrance gate, cottages, viewing and trekking sites and throughout BVNP where major attractions can be found.

Another "Good" rating of 2.88 mean was the same given to "Brochures, maps, and other printed materials". This result is notable on the displayed miniature of the BVNP showing the exact locations of the place and areas for tourist activities. There are also available locator maps and reading materials available at the reception area and information desk intended to visitors more particularly for foreign tourists.

Similarly, a "Good" rating of 2.76 mean was likewise experienced on the "Opportunities for learning about and experiencing natural and cultural attractions within the park". This finding signifies the conservation efforts of AGAP Bulusan in maintaining the naturalness of the place. The visitors' experience on the natural and cultural attractions are also enhanced by the competent park guides as well as on the strict implementation of the environmental conservation strategies in Bulusan where visitors also agree that informing them about local customs and practices promotes cultural respect and understanding and the same way with the orientation given to them prior to engagement in any activities foster environmental, social, and cultural conservation.

While, the "Opportunities to experience traditional ways of life" were rated "Fair" by the visitors of 2.38 mean. This result can be reflected on the prohibition of the park management not to allow leisure visitors to stay more than three (3) days within BVNP unless they are researchers or scientists conducting scientific studies. This finding relates with disagreement of visitors' response that there is an ample visitor interaction during local activities at the park. Furthermore, BVNP's management stressed that their prohibition in the length of stay of visitors is one of their measures to ensure the limitation of mass contact and exposure of the outsiders to park's inhabitants. 
In general, "Educational experience" of visitors were rated 2.93 mean interpreted as "Good".

\section{Escapism}

In terms of escapism experience of visitors in BVNP as shown in table 3, the "Accessibility to natural park's attractions" were rated "Very good" of 3.40 highest mean. This result can be credited to established trails, steps, and path walks directed to every attractions and areas with special interest. The presence of directional signs also contributed to good experience for accessibility of visitors.

The "Peacefulness of the place" under escapism were also rated "Very good" of 3.32 mean. As a protected natural area, it is one of the concerns that the BVNP's management is maintaining which is also experienced by the visitors through restricting the entry of vehicles and prohibiting the bringing of musical equipment or paraphernalia that may cause destruction of fauna and other living species. Hence, visitors are encouraged to observe and appreciate nature rather than urban lifestyle.

Another "Very good" rating of 3.25 mean was experienced to "Friendliness of people" in the park. This implies that the local residents and the park volunteers are really accommodating and hospitable with their tourist as reflected in their welcoming greetings, gestures, and actions in responding to tourist's needs. Their friendliness is also noticeable in providing assistance especially with those persons with disability (PWDs) and senior citizens.

Table 3: Escapism Experience in Bulusan Volcano Natural Park

\begin{tabular}{|c|c|c|c|}
\hline Escapism & Mean & S.D. & V.I. \\
\hline $\begin{array}{l}\text { 1. Personal safety and } \\
\text { security }\end{array}$ & 3.11 & 0.583 & Good \\
\hline $\begin{array}{l}\text { 2. Accessibility to natural } \\
\text { park's attractions }\end{array}$ & 3.40 & 0.549 & $\begin{array}{l}\text { Very } \\
\text { Good }\end{array}$ \\
\hline 3. Peacefulness of the place & 3.32 & 0.563 & $\begin{array}{l}\text { Very } \\
\text { Good }\end{array}$ \\
\hline 4. Novelty of experience & 2.43 & 0.589 & Fair \\
\hline $\begin{array}{l}\text { 5. Opportunity to stay in a } \\
\text { pristine natural } \\
\text { environment }\end{array}$ & 3.08 & 0.374 & Good \\
\hline 6. Friendliness of people & 3.25 & 0.481 & $\begin{array}{l}\text { Very } \\
\text { Good }\end{array}$ \\
\hline Overall & 3.10 & 0.343 & Good \\
\hline
\end{tabular}


The "Personal safety and security" were experienced "Good" as rated 3.11 mean by the respondents. BVNP has Mt. Bulusan Vanguards (MBV) and Forest Rangers to ensure that the capacity development will consider not only social and legislative strength but Law Enforcement as well. MBV helps intensify the protective measures for BVNP through providing organisational and legal security as well as economic aid for MBV and Forest Rangers. In addition, an orientation on the safety and security for visitors are also conducted by the park rangers or guides prior to engagement in any eco-adventure tours within Bulusan.

The respondents also gave "Good" rating of 3.08 mean with their experienced to "Opportunity to stay in a pristine natural environment". This rating implies that the visitors appreciate the significance of biodiversity and presence of wildlife with ecotourism value which highlights the three main peaks such as Bulusan Volcano, Sharp Peak, and Mt. Jormahan and the three lakes namely, Black Bird's Lake, Aguingay Lake, and Bulusan Lake.

While, it was "Fair" of 2.43 mean the "Novelty of experience" of visitors considering also that BVNP is not the only protected area promoted for ecotourism in Sorsogon and in Bicol region in general. Likewise, this result can be also linked with the type of tourist visiting the park which is commonly local visitors.

In summary, escapism in the park was experienced as "Good" by the visitors at 3.10 overall mean.

\section{Esthetic}

In line with esthetic experience in BVNP as presented in table 4, the "Quality of natural scenery and landscape environment" gained a highest mean of 3.18 followed by "Weather condition" of 3.12 mean interpreted as "Good" respectively by the respondents. This indicates that the park maintained the natural setting of the place as also one of the BVNP's management goals as a local conservation area and with the observed continued commitment of AGAP Bulusan to safeguard the entire park. Likewise, this conservation of Natural Park is also attributed to established resource protection strategies and with the support of government and non-government organisations such as DENR, DOT, UNDP, ILOVE Foundation, and other projects and programs like PRESERVE MRS Bulusan project, Tayo ang Kalikasan or "We Are Nature" Citizen's Movement, and Integrated Coastal Resource Management that are implemented towards conservations efforts. The physical carrying capacity of the place is also strictly observed by limiting the establishment of structural facilities that could 
alter the state of the natural environment. As such, most of the park activities are nature-based and does not require any machinery for operation.

Table 4: Esthetic Experience in Bulusan Volcano Natural Park

\begin{tabular}{|c|c|c|c|}
\hline Esthetic & Mean & S.D. & V.I. \\
\hline 1. Weather condition & 3.12 & 0.403 & Good \\
\hline $\begin{array}{l}\text { 2. Quality of natural scenery } \\
\text { and } \\
\text { landscape/environment }\end{array}$ & 3.18 & 0.430 & Good \\
\hline $\begin{array}{l}\text { 3. Organised tours } \\
\text { conducted by park } \\
\text { management }\end{array}$ & 3.02 & 0.454 & Good \\
\hline 4. Resting area/ viewing sites & 3.02 & 0.431 & Good \\
\hline $\begin{array}{l}\text { 5. Harmony of the } \\
\text { surroundings }\end{array}$ & 2.80 & 0.657 & Good \\
\hline Overall & 3.02 & 0.330 & Good \\
\hline
\end{tabular}

The "Organised tours conducted by park management" were also received "Good" experienced from the visitors of 3.02 mean. This finding can be attributed to varied outdoor recreational activities offered to visitors depending on the age bracket and level of adventure the tour group wants to engage in. Likewise, the park management is also working with their partner tour operators in promoting and likewise bringing visitors in BVNP. BVNP as an ecotourism destination gives emphasis on offering, scientific, educational, and recreational experiences.

Similarly, a "Good" rating of 3.02 was likewise experienced to "Resting area and viewing sites". This implies that these facilities give comfort for visitors which are also designed in harmony with the surroundings and to provide easy access to visitors while at the same time protect the natural resources.

Generally, "Esthetic experience" gained a grand mean of 3.02 as "Good".

\section{Summary on the Four Realms of Visitors' Experience in Bulusan Volcano Natural Park}

Table 5 shows the summary of ratings on the four realms of experience in BVNP. The visitors' experiences in the park were generally "Good" at 2.89 grand average mean. The highest rating was attributed to "Escapism" at 3.10 mean, followed by the 3.02 mean which is the "Esthetic", down to "Educational" at 2.93 mean, and an "Entertainment" experience which received the lowest mean of 2.50 and were respectively interpreted as "Good". 
Table 5: Summary on the Four Realms of Experience in Bulusan Volcano Natural Park

\begin{tabular}{|c|c|c|c|}
\hline Realms of Experience & Mean & S.D. & V.I. \\
\hline 1. Entertainment & 2.50 & 0.543 & Good \\
\hline 2. Educational & 2.93 & 0.301 & Good \\
\hline 3. Escapism & 3.10 & 0.343 & Good \\
\hline 4. Esthetic & 3.02 & 0.330 & Good \\
\hline Overall & 2.89 & 0.284 & Good \\
\hline
\end{tabular}

It can be noted that escapism is the most desired experience of visitors in the park which involves a higher level of engagement and active participation in the natural settings and the destination's environment. This experienced of visitors in the park are enhanced through accessibility to park's attractions, peacefulness of the place, friendliness of people, safety and security, opportunity to stay in a pristine natural environment, and novelty of experience. The feeling of being isolated from the urban society is what BVNP makes more significant to visitors.

The second realm of experience got the second highest mean was esthetic which is also closer with escapism as a passive and immersion where visitor enjoy the event without putting any effect on them. It is an experience that uses the senses and appreciation to actual set-up of the place. In BVNP, this experience is attributed to quality of natural scenery and landscape environment, weather condition; organised tours conducted by the park management; resting area and sites, and harmony of the surroundings which are all physically maintained by the park management and environmentally conserved by the AGAP Bulusan.

Visitors' educational experience was also positive as it is enhanced by the competent park guides, directional signages, information boards, IEC materials, and opportunity for learning about and experiencing natural and cultural attractions of the park. It is categorised for absorption and active participation in the realms of experience that increases the visitor skills and awareness through active participation in tours and other learning activities.

Lastly, the entertainment experience which were credited to good performance of park guides in the delivery of tour commentary, and water and land-based recreational activities that were enjoyed by the tourists. It is where the visitors are engaged in on-site or actual activities and other performances within the place. 


\section{Conclusion and Recommendations}

Bulusan Volcano Natural Park (BVNP) as a local conservation area is committed in conserving the environment and fostering socio-economic development of people in the destination through the active presence and sound leadership of civil society organisation called AGAP Bulusan, Inc. Their partnership and linkages with other agencies, as well as, various projects and activities implemented have strengthened ecotourism business and conservation efforts within protected area. BVNP embraces the principles of community-based conservation and ecotourism destination which according to King (2010), that economic development and natural resources conservation is compatible goals of the people. This concept is also supported by Goodwin (1996) as it contributes to the maintenance of species and habitats through a contribution to conservation and by providing revenue to the local community, therefore, demonstrating a sense of responsibility as a source of their livelihood and income.

BVNP as visitors' destination has possessed good ecotourism attributes which are manifested from the experiences of visitors along with entertainment, educational, escapism, and esthetic. It can be observed that escapism is the most desired experience of visitors in the park which involves a higher level of engagement and active participation in the natural settings and the destination's environment. The feeling of being isolated from the urban society is what BVNP makes more significant to visitors. According to Wolf, Croft and Green (2019).), environment changes people to go outside places to find solitude and escape from societal stress in the urban. Tourist travel with nature because they want to feel and learn from the natural environment, socially engage with other people with the same interest, and actively interact with park's resources and activities during their visit. Relatively, the park's esthetic was also experienced good which is also closer with escapism as a passive and immersion where visitor enjoy the event without putting any effect on them. It is an experience that uses the senses and appreciation to actual set-up of the place.

Visitors' educational experience was also positive as it is enhanced by the competent park guides, directional signages, information boards, IEC materials, and opportunity for learning about and experiencing natural and cultural attractions of the park. It is categorised for absorption and active participation in the realms of experience that increases the visitor skills and awareness through active participation in tours and other learning activities. Lastly, the entertainment experience which were credited to good performance of park guides in the delivery of tour commentary, and water and land-based recreational activities that were enjoyed by the tourists. It is where the visitors 
are engaged in on-site or actual activities and other performances within the place.

These findings of positive visitors' experience are enhanced by sound resource protection strategies towards sustainable ecotourism and protected area conservation being implemented in BVNP. These are the strategies on social and environmental conservation which are effective and more given emphasis in BVNP. Likewise, with physical or behavioural conservation strategies which are also recognised effective mechanisms in managing visitors' use (Rebuya, 2020).

Although entertainment was experienced good, products should still be improved to give more authentic cultural (tangible and intangible) experience. These can be enhanced through revival of authentic cultural performances, development and production of locally handcrafted products/souvenirs, and patronisation of local cuisines. The reinforcement of authentic local traditions, practices, and performances should also be given attention to provide more relevant cultural experience to visitors by means of conducting cultural mapping and trainings and workshops. According to Lasarte (2020) an understanding of visitors' travel desires and experiences is at core of the successful tourism destination.

Further studies can be conducted on the relationship of park's visitor experience and resource protection strategies and visitor impact management.

\section{Acknowledgments}

The author acknowledges the support of Bulusan Volcano Natural Park's administration particularly to Aggrupation of Advocates for Environmental Protection (AGAP) Bulusan, Inc for their assistance and provision of necessary data and information in the completion of the study. A special thank is also accorded to Engr. Kier P. Gasga for his technical support. In the same way, to his family and friends for their unconditional love and motivation.

\section{References}

ASEAN Centre for Biodiversity. (2010). ASEAN biodiversity outlook. Los Baños: ASEAN Centre for Biodiversity.

Bejinaru, R. \& Cozorici, A. (2016). Challenges for Romanian ecotourism destinations. Journal of Tourism - Studies and Research in Tourism, 22. Retrieved from http://www.revistadeturism.ro/rdt/article/view/352/233 
Bulusan Volcano Natural Park (BVNP) as local conservation area. (n.d.). Retrieved

https://newcapp.files.wordpress.com/2014/11/lca_bulusan1.pdf

Ceballos-Lascurain, H. (1996). Tourism, ecotourism and protected areas: The state of nature-based tourism around the world and guidelines for its development. Gland, Switzerland: IUCN.

Coates, D. (2016). Strategic plan for biodiversity (2011-2020) and the Aichi biodiversity targets. In C. M. Finlayson, M. Everard, K. Irvine, R. McInnes, B. Middleton, A. van Dam, \& N. C. Davidson (Eds.), The Wetland book I: Structure and function, management, and methods (pp. 1-7). Dordrecht: Springer. https://doi.org/10.1007/978-94-007-6172-8_119-2

Coria, J., \& Calfucura, E. (2012). Ecotourism and the development of indigenous communities: The good, the bad, and the ugly. Ecological Economics, 73, 4755. https://doi.org/10.1016/j.ecolecon.2011.10.024

Cruz, R. (2017). Ecotourism. Manila: Rex Book Store, Inc.

Denzin, N. K., \& Lincoln, Y. S. (1994). Handbook of qualitative research. Thousand Oaks: SAGE Publications.

Frank, G., \& Polkinghorne, D. (2010). Qualitative research in occupational therapy: From the first to the second generation. OTJR: Occupation, Participation and Health, 30(2), 51-57. https://doi.org/10.3928/1539449220100325-02

Goodwin, H. (1996). In pursuit of ecotourism. Biodiversity $\mathcal{E}$ Conservation, 5, 277291. https://doi.org/10.1007/BF00051774

Huijbens, E., \& Benediktsson, K. (2013). Inspiring the visitor? Landscapes and horizons of hospitality. Tourist Studies, 13(2), 189-208. https://doi.org/10.1177/1468797613490378

Jager, E., \& Halpenny, E. (2012). Supporting the CBD Aichi biodiversity conservation targets through park tourism: A case study of Parks Canada's visitor experience programme. Parks, 18(2), 79-92. https://doi.org/10.2305/iucn.ch.2012.parks-18-2.ej.en

Jurowski, C. (2009). An Examination of the four realms of tourism experience theory. International CHRIE Conference-Refereed Track, 23. Retrieved from https://scholarworks.umass.edu/cgi/viewcontent.cgi?article=1054\&context= refereed

Kafle, N. (2014). Nature based tourism and visitor experiences in Chitwan National Park. Undergraduate thesis, School of Tourism and Hospitality Management, Lapland University of Applied Sciences, Rovaniemi, Finland. 
Kamri, T., \& Radam, A. (2013). Visitors' visiting motivation: Bako National Park, Sarawak. Procedia-Social And Behavioral Sciences, 101, 495-505. https://doi.org/10.1016/j.sbspro.2013.07.223

King, B. (2010). Conservation geographies in sub-Saharan Africa: The politics of national parks, community conservation and peace parks. Geography Compass, 4(1), 14-27. https://doi.org/10.1111/j.1749-8198.2009.00288.x

Lasarte, E. (2020). Travel decision and destination experiences in the Islands of Caramoan, Philippines: A visitors' descriptive evaluation. International Journal of Innovative Science and Research Technology, 5(7). https://doi.org/10.38124/IJISRT20JUL022

Leung, Y. F., Spenceley, A., Hvenegaard, G. \& Buckley, R. (2018). Tourism and visitor management in protected areas: Guidelines for sustainability. Gland, Switzerland: IUCN. https://doi.org/10.2305/IUCN.CH.2018.PAG.27.en

Lim, R. D. (2012). Principles and scopes of tourism. Manila: Minshapers Co.

Lim, R. D. (2013). Ecotourism with tourism planning and development essentials. Manila: Mindshapers Co.

Manning, R. (2001). Visitor experience and resource protection: A framework for managing the carrying capacity of national parks. Journal of Park and Recreation Administration, 19(1), 93-108.

Miller, M., Carter, R., Walsh, S., \& Peake, S. (2014). A conceptual framework for studying global change, tourism, and the sustainability of iconic national parks. The George Wright Forum, 31(3), 256-269

Newsome, D., Moore, S., \& Dowling, R. (2013). Natural area tourism (2nd ed.). Bristol: Channel View Publications.

Otuokon, S., Chai, S. \& Beale, M. (2012). Using tourism to conserve the mist forest and mysterious cultural heritage of the Blue and John Crow Mountains National Park, Jamaica. Parks, 18(2), 145-155. https://doi.org/10.2305/IUCN.CH.2012.PARKS-18-2.SO.en

PHILIPPINES: Bulusan volcano (as of 22 Nov 2010) - Location Map. Retrieved from https://reliefweb.int/map/philippines/philippines-bulusan-volcano22-nov-2010-location-map

Pine, B. J., \& Gilmore, J. H. (1998). Welcome to the experience economy. Harvard business review, 76(4), 97-105.

Pine, B. J., \& Gilmore, J. H. (1999). The experience economy: Work is theatre $\mathcal{E}$ every business a stage. Boston: Harvard Business School Press.

Radder, L., \& Han, X. (2015). An examination of the museum experience based on pine and Gilmore's experience economy realms. The Journal of Applied Business Research, 31(2). 
Rebuya, N. (2020). Resource protection strategies towards sustainable ecotourism and protected area conservation: A visitors' evaluation in Bulusan Volcano Natural Park, Philippines. International Journal of Tourism \& Hospitality Reviews, 7(2), 12-19. https://doi.org/10.18510/ijthr.2020.722

Shyuji, T. (2015). Did localisation of community-based conservation succeed? A case study on community-based sea turtle conservation in Ma 'Daerah Sea Turtle Sanctuary. JATI-Journal of Southeast Asian Studies, 20, 94-106. https://doi.org/10.22452/jati.vol20no1.6

Snyman, S. (2012). The impact of land management systems on community attitudes towards tourism and conservation in six South African countries. Parks, 18(2), 21-32. https://doi.org/10.2305/IUCN.CH.2012.PARKS-182.SS.en

Thapa, B., \& Lee, J. (2017) Visitor experience in Kafue National Park, Zambia. Journal of Ecotourism, 16(2), 112-130. https://doi.org/10.1080/14724049.2016.1245737

Wang, L., Zhong, L., Zhang, Y., \& Zhou, B. (2014). Ecotourism environmental protection measures and their effects on protected areas in China. Sustainability, 6(10), 6781-6798. https://doi.org/10.3390/su6106781

Weiler, B., Moore, S., \& Moyle, B. (2013). Building and sustaining support for national parks in the 21st century: Why and how to save the national park experience from extinction. Journal of Park and Recreation Administration, 31(2), 115-131.

Wolf, I., Croft, D., \& Green, R. (2019). Nature conservation and nature-based tourism: A paradox? Environments, 6(9), 104, https://doi.org/10.3390/environments6090104 